\title{
An Anionic Resin Modified by di-2-Pyridyl Ketone Salicyloylhydrazone as a New Solid Preconcentration Phase for Copper Determination in Ethanol Fuel Samples
}

\author{
Samara Garcia and Ivanise Gaubeur* \\ Centro de Ciências Naturais e Humanas, Universidade Federal do ABC, Rua Santa Adélia, 166, \\ 09210-170 Santo André-SP, Brazil
}

\begin{abstract}
A adsorção do DPKSH em resina aniônica foi investigada a $25 \pm 1{ }^{\circ} \mathrm{C}$ e em pH $12 \mathrm{com}$ base em três modelos cinéticos pseudo-primeira ordem, pseudo-segunda ordem e difusão intra-partícula. Os dados experimentais foram aplicados com sucesso aos modelos das isotermas de Langmuir, Freundlich e Dubinin-Radushkevich (D-R). A resina aniônica modificada com DPKSH foi usada na determinação espectrofotométrica do cobre após pré-concentração em linha. Nas melhores condições, foi observada uma resposta linear entre 20 e $80 \mu \mathrm{g} \mathrm{L}^{-1}$, limites de detecção e quantificação estimados em 0,5 e 1,8 $\mu \mathrm{g} \mathrm{L}^{-1}$, respectivamente, com um nível de confiança de $95 \%$, e um fator de pré-concentração igual a 11 . O desvio padrão relativo foi estimado em $2,6 \%$ para a concentração de $32 \mu \mathrm{g} \mathrm{L}^{-1} \mathrm{Cu}$ (II) $(\mathrm{n}=20)$. Os resultados obtidos na determinação de cobre em amostras de etanol combustível apresentaram concordância, com um nível de confiança de 99\%, aos obtidos por espectrometria de absorção atômica com chama (F AAS).
\end{abstract}

The adsorption of DPKSH onto anionic resin was investigated at $25 \pm 1{ }^{\circ} \mathrm{C}$ and $\mathrm{pH} 12$ on the basis of three kinetic models including pseudo-first order, pseudo-second order and intraparticle diffusion. Isotherm equations including Langmuir, Freundlich and Dubinin-Radushkevich (D-R) were successfully applied to model the experimental data. An anionic resin loaded with DPKSH was used in a flow system for the in-line concentration of copper prior to spectrophotometric determination. Under optimized conditions, a linear response was observed between 20 and $80 \mu \mathrm{g} \mathrm{L}^{-1}$, with limits of detection and quantification estimated at 0.5 and $1.8 \mu \mathrm{g} \mathrm{L}^{-1}$, respectively, at the $95 \%$ confidence level with an enrichment factor of 11 . The relative standard deviation was estimated to be $2.6 \%$ for $32 \mu \mathrm{g} \mathrm{L}{ }^{-1} \mathrm{Cu}$ (II) $(\mathrm{n}=20)$. The results obtained for copper determination in ethanol fuel samples agreed with those achieved by flame atomic absorption spectrometry (F AAS) at the $99 \%$ confidence level.

Keywords: preconcentration, DPKSH, flow analysis, molecular spectrophotometry, ethanol fuel sample

\section{Introduction}

In spite of the recent advances in instrumentation and improvements in selectivity and sensitivity, there is a need for preconcentration and separation of trace elements prior to analyses to achieve low limits of detection and to remove constituents that interfere with the matrix. ${ }^{1-4}$

Several strategies are used for separation and preconcentration, such as liquid-liquid, solid-liquid and cloud point extraction. ${ }^{4-7}$ In comparison to other strategies, solid-liquid extraction provides simplicity, lower

*e-mail: ivanise.gaubeur@ufabc.edu.br sample contamination and higher enrichment factors, in addition to simple coupling to flow systems, improved sampling throughput and minimal sample and reagent consumption. ${ }^{8-11}$

Recently a number of sorbents have been used for the in-line preconcentration and determination of metal ions including polymeric resins. ${ }^{1,10,12}$ The Amberlite XAD4 resin was modified with $\beta$-nitroso- $\alpha$-naphthol and applied to copper preconcentration and determination in food samples. Modifications included the resin functionalization or impregnation of copolymer with a solution containing $\beta$-nitroso- $\alpha$-naphthol. Both modifications resulted in resins with similar analytical characteristics. $^{12}$ 
Di-2-Pyridyl ketone salicyloylhydrazone (DPKSH) is a complexing reagent that is presently used in spectrophotometric method development. DPKSH was adsorbed onto silica gel and Amberlite resins (XAD-2 and XAD-7), and the adsorption was investigated using kinetic and isotherm models. ${ }^{13-15}$

In ethanolic/aqueous solution, DPKSH is in tautomeric equilibrium with the (I) ketonic and (II) enolic form, Scheme 1.

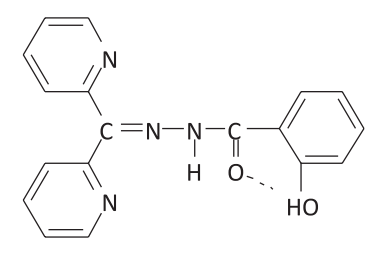

I

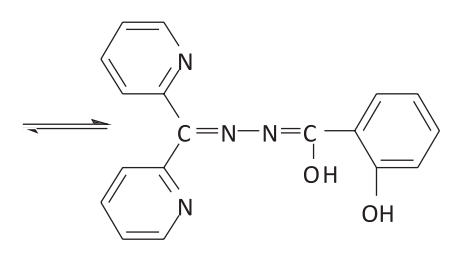

II
Scheme 1. DPKSH tautomeric equilibrium.

DPKSH may be present in solution as different species and is dependent on the $\mathrm{pH}$ of the solution. At a $\mathrm{pH}$ between 3.6 and 6.7, neutral species represented by $\mathrm{RN}$ are predominant. At $\mathrm{pH} \leq 3.5$, protonation of the pyridine nitrogen occurs $\left(\mathrm{K}_{1} 3.16 \times 10^{-4} \mathrm{~mol} \mathrm{~L}^{-1}\right)$ and the protonated species is predominant and is represented by $\mathrm{RNH}^{+}$. At $\mathrm{pH} \geq 6.7$, anionic species represented by $\mathrm{RO}^{-}$are predominant $\left(\mathrm{K}_{2} 1.41 \times 10^{-7} \mathrm{~mol} \mathrm{~L}^{-1}\right)$. Deprotonation of the enolic form of DPKSH is represented by $\mathrm{ROH}^{16}$

This study focused on the evaluation of an anionic resin modified with DPKSH and the utilization of the modified resin as a solid phase for in-line copper separation and preconcentration. The mechanism of adsorption was obtained through kinetic and isotherm models. A flow system with in-line preconcentration on a mini-column packed with an anionic resin modified by DPKSH was developed. Chemical and hydrodynamic parameters were investigated and the procedure was applied to copper spectrophotometric determination in ethanol fuel samples.

\section{Experimental}

\section{Instrumentation}

An UV-Vis Cary 50 spectrophotometer (Varian, Palo Alto, CA, USA) equipped with a $1.00 \mathrm{~cm}$ quartz cell (Hellma, Müllheim, Germany) was used to determine the absorbance of DPKSH solutions and Cu (II)/DKPSH complexes.

Solutions were mixed (DPKSH and IRA 402) with a MA-140 Marconi shaker (Piracicaba, SP, Brazil) at a controlled speed. The mixtures were centrifuged with a QM222TM centrifuge (Quimis, São Paulo, Brazil).

The measurement of $\mathrm{pH}$ was performed with a Metrohm 654 pHmeter (Herisau, Switzerland) equipped with a Metrohm combined glass electrode. The $\mathrm{Ag} / \mathrm{AgCl}$ reference electrode was filled with $3 \mathrm{~mol} \mathrm{~L}^{-1} \mathrm{NaCl}$.

The flow system was designed with a Gilson Minipuls Evolution peristaltic pump (Paris, France) equipped with $0.7 \mathrm{~mm}$ Tygon ${ }^{\circledast}$ tubes for the propulsion of fluid.

An Analyst 200 flame atomic absorption spectrometer (PerkinElmer, Norwalk, CT, USA) equipped with deuterium background correction and copper hollowcathode lamps as radiation sources was used for the determination of copper in ethanol fuel samples. The instrumental parameters were adjusted according to the manufacturer's recommendations.

\section{Reagents and solutions}

All solutions were prepared with analytical grade reagents and deionized water, obtained from Milli-Q system (Millipore, Billerica, MA, USA). Copper reference solutions were prepared by diluting $1.0 \mathrm{~g} \mathrm{~L}^{-1}$ stock solutions Titrisol (Merck, Darmstadt, Germany). Solutions, such as those used to evaluate the proposed method selectivity, were prepared by dissolving their salts into deionized water.

Buffer solutions containing $\mathrm{CH}_{3} \mathrm{COOH} / \mathrm{CH}_{3} \mathrm{COONa}$ at $\mathrm{pH} 4.0\left(1.0 / 0.20 \mathrm{~mol} \mathrm{~L}^{-1}\right), \mathrm{pH} 4.7\left(0.10 / 0.10 \mathrm{~mol} \mathrm{~L}^{-1}\right)$, pH $5.0\left(0.50 / 1.0 \mathrm{~mol} \mathrm{~L}^{-1}\right)$, pH $5.5\left(0.20 / 1.3 \mathrm{~mol} \mathrm{~L}^{-1}\right)$ and pH $6.0\left(0.10 / 2.0 \mathrm{~mol} \mathrm{~L}^{-1}\right)$ and $\mathrm{CH}_{3} \mathrm{COONH}_{4}$ at $\mathrm{pH} 7.0$ $\left(1.0 \mathrm{~mol} \mathrm{~L}^{-1}\right)$ were used for the adjustment of the $\mathrm{pH}$.

DPKSH was synthesized according to a procedure reported in previous paper. ${ }^{7}$ The solutions of DPKSH were prepared by dissolving the reagent in ethanol absolute from Merck and diluted in different ethanol concentrations when needed.

\section{Adsorption experiments}

DPKSH adsorption kinetics and isotherms were determined using the solution depletion method. In stoppered plastic tubes, $0.200 \mathrm{~g}$ of the anionic resin was shaken with $10 \mathrm{~mL}$ of a solution comprised of DPKSH and 3\% v/v ethanol at pHs 1, 4.7 and 12. In the kinetics study, the mixture was maintained under agitation and an aliquot of supernatant was collected every $20 \mathrm{~min}$ up to $240 \mathrm{~min}$, while in the adsorption isotherm study the resulting mixture was then kept in contact for $2 \mathrm{~h}$.

The concentration of DPKSH, at the supernatant aliquots, was determined from the absorption with parameters from the following analytical curves: 
pH 1: $\quad \mathrm{A}_{332 \mathrm{~mm}}=0.010+2.21 \times 10^{4} \times \mathrm{C}_{\mathrm{DPKSH}}, \quad \mathrm{r}=0.9983$ (1) $\mathrm{pH} 4.7: \mathrm{A}_{319 \mathrm{~mm}}=-0.017+1.91 \times 10^{4} \times \mathrm{C}_{\mathrm{DPKSH}}, \mathrm{r}=0.9989$ (2) $\mathrm{pH} 12: \mathrm{A}_{315 \mathrm{~mm}}=-0.011+1.37 \times 10^{4} \times \mathrm{C}_{\mathrm{DPKSH}}, \mathrm{r}=0.9989$

\section{Preparation of the solid adsorbent and mini-column}

Amberlite ${ }^{\circledR}$ IRA 402 (Aldrich Chemical, Saint Louis, MO, USA), an anion exchanger with a particle size of $0.60-0.75 \mathrm{~mm}$ and an exchange capacity of 1.2 equiv. $\mathrm{L}^{-1}$, was used in this work. The chloride form of the resin was treated with a 1:1:2 v/v/v HCl:ethanol: $\mathrm{H}_{2} \mathrm{O}$ solution in a bath for $3 \mathrm{~h}$. The resin was collected on a Büchner funnel with filter paper and repeatedly washed with deionized water until the filtrate was near neutral $(\mathrm{pH} c a .6)$. The washed resin was dried in a desiccator for 2 days to remove any adsorbed water.

After the treatment as stated above, resin IRA 402 was modified by adding $1 \mathrm{~g}$ of such in contact with $10 \mathrm{~mL}$ of DPKSH $2.2 \times 10^{-4} \mathrm{~mol} \mathrm{~L}^{-1}$ prepared in medium of $\mathrm{NaOH}$ $(\mathrm{pH} 12)$ and $3 \% \mathrm{v} / \mathrm{v}$ ethanol. The resulting mixture was under agitation at constant both speed and temperature for $24 \mathrm{~h}$. Finally, the modified resin was then washed with deionized water.

A mini-column was packed with $95 \mathrm{mg}$ of modified anionic resin. The ends of the mini-column were fitted with glass wool to prevent changes in height bend.

Flow system

In the flow system (Figure 1a), a sample (S) of a $\mathrm{Cu}$ (II) solution was pumped at $6.3 \mathrm{~mL} \mathrm{~min}^{-1}$ and merged with a buffer solution $\left(\mathrm{B}, \mathrm{CH}_{3} \mathrm{COOH} / \mathrm{CH}_{3} \mathrm{COONa}\right)$ at $\mathrm{pH} 5.5$ and also pumped at $4.8 \mathrm{~mL} \mathrm{~min}{ }^{-1}$. The resulting sample was then pumped through a mini-column (C) packed with anionic resin modified by the addition of DPKSH, for $60 \mathrm{~s}$ loading time. The injector-commutator valve (IC) was commutated to injection (Figure 1b) and copper was eluted with $100 \mu \mathrm{L}(\mathrm{EV})$ of a $0.05 \mathrm{~mol} \mathrm{~L}^{-1} \mathrm{HNO}_{3}$ solution (E) at $6.3 \mathrm{~mL} \mathrm{~min}^{-1}$. The resulting solution was then merged with $4.8 \mathrm{~mL} \mathrm{~min}^{-1}$ of reagent $\left(\mathrm{R}, 1.5 \times 10^{-4} \mathrm{~mol} \mathrm{~L}^{-1} \mathrm{DPKSH}\right.$ and $7.5 \% \mathrm{v} / \mathrm{v}$ ethanol, $\mathrm{pH}$ 5.5). After the solution passed through a $10 \mathrm{~cm}$ reaction coil (RC), the $\mathrm{Cu}(\mathrm{II}) / \mathrm{DPKSH}$ complex was detected (D) at $378 \mathrm{~nm}$. Signals were measured as peak heights using the instrument software. Although the proposed system is manually operated, it can be easily automated by modern methods, such as multicommutation. ${ }^{10}$

\section{Samples}

Commercial ethanol fuel samples were acquired from a local gas station and $\mathrm{Cu}$ (II) determination was carried out in triplicate by the standard additions method. Volumes of $75 \mathrm{~mL}$ of samples were transferred to volumetric flasks and standard $\mathrm{Cu}$ (II), $\mathrm{NaF}$ (to avoid $\mathrm{Fe}(\mathrm{III})$ interference) and $\mathrm{Na}_{2} \mathrm{SO}_{4}$ (to recover copper from complexes with organic species) ${ }^{17}$ solutions were added. Lastly, deionized water was added so that the final volume of the solution was $100 \mathrm{~mL}$.

\section{Results and Discussion}

\section{Adsorption kinetics}

The DPKSH $\left(4.0 \times 10^{-5} \mathrm{~mol} \mathrm{~L}^{-1}\right)$ mass variation retained per gram of resin as a time function is shown in Figure 2a for solutions with $\mathrm{pHs} 1,4.7$ and 12. The maximum exchange with DPKSH is achieved after $200 \mathrm{~min}$ at $\mathrm{pH} 4.7$ and in $60 \mathrm{~min}$ at $\mathrm{pH} 12$. At $\mathrm{pH} 1$, the maximum exchange was not observed until $240 \mathrm{~min}$.

Considering the superior capacity for adsorption of DPKSH onto an IRA 402 resin at $\mathrm{pH} \mathrm{12,} \mathrm{kinetic} \mathrm{and}$ isotherm studies were perfgormed at this $\mathrm{pH}$. To investigate the mechanism of ion exchange, a simple kinetic model was used to test the experimental data. This was achieved by applying the Lagergren expression, ${ }^{13,18,19}$ which is the

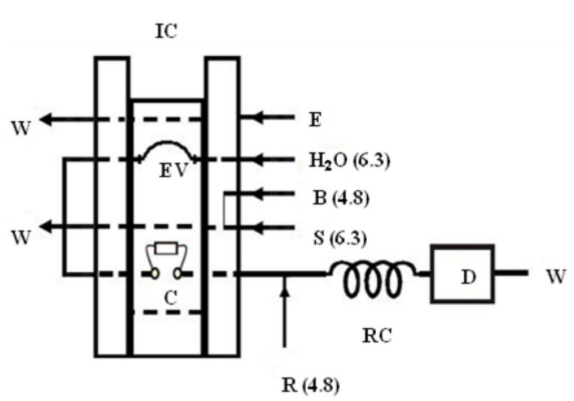

(b)

Figure 1. Flow diagram system for copper (II) determination. IC: injector-commutator valve, RC: $10 \mathrm{~cm}$ reaction coil, C: mini-column packed with resin modified by the addition of DPKSH, E: eluent $\left(\mathrm{HNO}_{3}, 0.05 \mathrm{~mol} \mathrm{~L}^{-1}\right)$, EV: eluent volume, $\mathrm{S}$ : $\mathrm{Cu}(\mathrm{II})$ sample, B: buffer solution $\left(\mathrm{CH}_{3} \mathrm{COOH} \mathrm{CH}_{3} \mathrm{COONa}\right)$, $\mathrm{R}$ : DPKSH and buffer solution $\left(\mathrm{CH}_{3} \mathrm{COOH} / \mathrm{CH}_{3} \mathrm{COONa}\right), \mathrm{W}$ : waste and D: UV-Vis spectrophotometer at $378 \mathrm{~nm}$. 

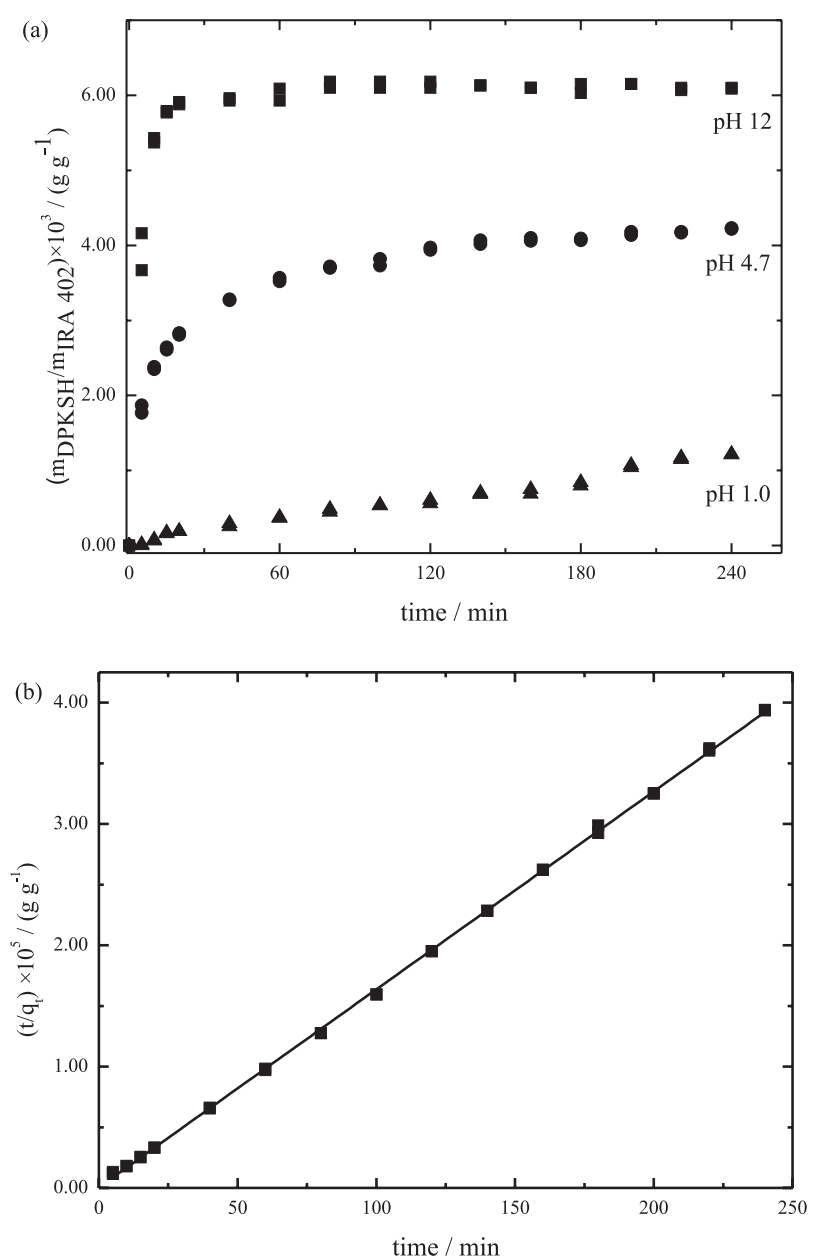

Figure 2. (a) Dependence of adsorbed mass of DPKSH per unit mass of IRA 402 on time at pHs 1, 4.7 and 12 (b) test of pseudo-second order adsorption of DPKSH onto IRA 402 at pH 12.

first equation developed for the description of adsorption in liquid-solid systems based on solid capacity.

$\frac{\mathrm{dq}_{\mathrm{t}}}{\mathrm{dt}}=\mathrm{k}_{1}\left(\mathrm{q}_{\max }-\mathrm{q}_{\mathrm{t}}\right)$

where $k_{1}$ is the rate constant of a pseudo-first order process, $\mathrm{q}_{\max }$ denotes the maximum amount of exchange (g DPKSH g ${ }^{-1}$ IRA 402) and indicates the adsorption capacity corresponding to monolayer coverage, $\mathrm{q}_{t}$ is the amount of DPKSH retained on IRA $402\left(\mathrm{~g} \mathrm{~g}^{-1}\right)$ when $\mathrm{t} \neq 0$ and $\mathrm{t}_{\max }$. After integration and application of the initial conditions where $\mathrm{q}_{\mathrm{t}}=0$ at $\mathrm{t}=0$ and the conditions at equilibrium where $\mathrm{q}_{\mathrm{ads}}=\mathrm{q}_{\mathrm{t}}$ for each time, $\mathrm{t}$, equation 4 becomes:

$\log \left(\mathrm{q}_{\max }-\mathrm{q}_{\mathrm{t}}\right)=\log \mathrm{q}_{\text {max }, \text { calc }}-\frac{\mathrm{k}_{1}}{2.303} \mathrm{t}$

The correlation coefficient obtained from the pseudofirst order model at $\mathrm{pH} 12$ was not satisfactory and the calculated value of $q_{\text {max,cal }}$ was quite different from the value of $q_{\max }$ observed in the experimental kinetic study, Figure 2a. These results suggest that adsorption of DPKSH on the anionic resin does not follow a pseudo-first order model.

The exchange kinetics may be described by a pseudosecond order equation..$^{13,18-21}$ The differential equation may be expressed by:

$\frac{\mathrm{dq}_{\mathrm{t}}}{\mathrm{dt}}=\mathrm{k}_{2}\left(\mathrm{q}_{\text {max.calc }}-\mathrm{q}_{\mathrm{t}}\right)^{2}$

where $\mathrm{k}_{2}$ is the rate constant of the pseudo-second order process and $\mathrm{q}_{\mathrm{t}}$ and $\mathrm{q}_{\text {max,calc }}$ are as indicated in equation 4 .

Integrating equation 5 and applying boundary conditions gives:

$$
\frac{\mathrm{t}}{\mathrm{q}_{\mathrm{t}}}=\frac{1}{\mathrm{k}_{2} \mathrm{q}_{\text {max } \text { calc }}^{2}}+\frac{1}{\mathrm{q}_{\text {max } \text { calc }}} \mathrm{t}
$$

The second-order constant $\left(\mathrm{k}_{2}\right)$ and the maximum amount of DPKSH retained $\left(\mathrm{q}_{\text {max,calc }}\right)$ may be calculated from the intercept and the slope of equation 5 a between $\mathrm{t} / \mathrm{q}_{\mathrm{t}}$ and $\mathrm{t}$. Figure $2 \mathrm{~b}$ shows $\left(\mathrm{t} / \mathrm{q}_{\mathrm{t}}\right) v s$. $\mathrm{t}$ and the values of $\mathrm{k}_{2}$, $\mathrm{q}_{\text {max,calc }}$ and $\mathrm{r}^{2}$ which are $(6.07 \pm 1.22) \times 10^{3} \mathrm{~min}^{-1} \mathrm{~g}$ resin $\mathrm{g}^{-1}$ DPKSH, $(6.13 \pm 0.01) \times 10^{-4} \mathrm{~g} \mathrm{DPKSH} \mathrm{g}^{-1}$ resin and 0.9999, respectively. The $\mathrm{q}_{\max , \text { calc }}$ agrees with the $\mathrm{q}_{\max }$ obtained from kinetic experimental data $\left(6.10 \times 10^{-4} \mathrm{~g}^{\mathrm{DPKSH} \mathrm{g}}{ }^{-1}\right.$ resin $)$ and the value of $\mathrm{r}^{2}$ is excellent. Thus, the adsorption of DPKSH at $\mathrm{pH} 12$ proceeds according to the pseudo-second order model.

Considering the fact that pseudo-first order equation $4 \mathrm{a}$ and pseudo-second order equation 5 a models cannot identify a mechanism involving diffusion, the intraparticle diffusion model ${ }^{14,20,21}$ was tested using the following equation:

$\mathrm{q}_{\mathrm{t}}=\mathrm{k}_{\mathrm{p}} \mathrm{t}^{1 / 2}+\mathrm{C}$

$\mathrm{k}_{\mathrm{p}}$ is the rate constant for intraparticle diffusion and $\mathrm{C}$ is the intercept.

According to this model, if a straight line that passes through the origin is obtained from a plot of $\mathrm{q}_{\mathrm{t}} v s . \mathrm{t}^{1 / 2}$, the mechanism of adsorption involves diffusion and the slope of the linear curve is the rate constant of intraparticle transport $\left(\mathrm{k}_{\mathrm{p}}\right)$. Experimental data $\left(\mathrm{q}_{\mathrm{t}}, \mathrm{t}^{1 / 2}\right)$ at $\mathrm{pH} 12$ were applied to equation 6 and a diffusion mechanism did not fit the results.

\section{Adsorption isotherms}

To describe the adsorption equilibria, three commonly used mathematical expressions were applied to the experimental data. These equations correspond to the Freundlich, Langmuir and Dubinin-Radushkevich (D-R) isotherms models. ${ }^{14,15,18,19}$ 
The Langmuir model ${ }^{22}$ was originally developed to represent chemisorption on well-defined localized adsorption sites with identical adsorption energies. The Langmuir model also assumes that adsorption is independent of the surface coverage and interaction between adsorbed molecules does not occur. Maximum adsorption is achieved when the surface of the adsorbent is covered with a monolayer of adsorbate. The linearized form of Langmuir isotherm is expressed as follows:

$$
\frac{1}{\mathrm{~m}_{\mathrm{ads}}}=\frac{1}{\mathrm{~m}_{\mathrm{ads}}^{\max } \mathrm{K}_{\mathrm{L}} \mathrm{C}_{\text {eq }}}+\frac{1}{\mathrm{~m}_{\text {ads }}^{\max }}
$$

where $\mathrm{m}_{\text {ads }}$ represents the amount of DPKSH adsorbed per unit of resin $\left(\mathrm{g} \mathrm{g}_{\text {IRA 402 }}^{-1}\right), \mathrm{m}_{\text {ads }}^{\max }$ is the maximum amount of solute retained (g) per gram of IRA 402 (the adsorption capacity), $\mathrm{C}_{\mathrm{eq}}$ is the equilibrium concentration of DPKSH in solution $\left(\mathrm{g} \mathrm{L}^{-1}\right)$ and $\mathrm{K}_{\mathrm{L}}$ is the Langmuir constant which is related to the equilibrium constant of adsorption.

Figure 3 a shows the experimental data for $1 / \mathrm{m}_{\text {ads }} v s .1 / \mathrm{C}_{\text {eq }}$ for IRA 402/DPKSH at pH 12. The curve was fitted using Origin 7.5 software by adjusting the experimental data to equation 7 . The parameters $\mathrm{K}_{\mathrm{L}}$ and $\mathrm{m}_{\text {ads }}^{\max }$ are $(95.5 \pm 0.7) \mathrm{L} \mathrm{g}^{-1}$ and $(8.58 \pm 0.01) 10^{-4} \mathrm{~g}_{(\mathrm{DPKSH}) \mathrm{g}^{-1}}$ (IRA 402) at pH 12, respectively. The solid lines shown in Figure $3 \mathrm{a}$ were calculated by using parameters obtained from experimental values and an excellent fit was observed.

The Freundlich adsorption isotherm ${ }^{23}$ gives an empirical expression encompassing an exponential distribution of active sites. The model takes either a monolayer or multilayer adsorption that is indefinitely increased irrespective of the adsorbate concentration. This model also assumes that the adsorbent surface is energetically heterogeneous.

The linearized form of Freundlich isotherm is expressed as follows:

$\log \mathrm{m}_{\mathrm{ads}}=\log \mathrm{K}_{\mathrm{F}}+\frac{1}{\mathrm{n}} \log \mathrm{C}_{\mathrm{eq}}$

where $\mathrm{m}_{\mathrm{ads}}$ and $\mathrm{C}_{\mathrm{eq}}$ are as indicated in the Langmuir isotherm, $\mathrm{K}_{\mathrm{F}}$ is the empirical constant and $1 / \mathrm{n}$ is related to the energetic heterogeneity of adsorption sites.

The Freundlich constants $1 / \mathrm{n}$ and $\mathrm{K}_{\mathrm{F}}$ were determined from the slope and intercept of plots of $\log \mathrm{m}_{\text {ads }} v s . \log \mathrm{C}_{\mathrm{eq}}$ at $\mathrm{pH}$ 12, which are shown in Figure 3b. Numerical values of the adsorption capacity, $\mathrm{K}_{\mathrm{F}}$ and $1 / \mathrm{n}$, indicate the energy and intensity of adsorption and are (86 \pm 9$) \mathrm{g} \mathrm{g}^{-1}$ and $(0.65 \pm$ 0.02 ), respectively. A value of $\mathrm{n}$ between 1 and 10 indicates that adsorption is favored. ${ }^{19}$

To distinguish between physical and chemical adsorption, the experimental data were applied to the
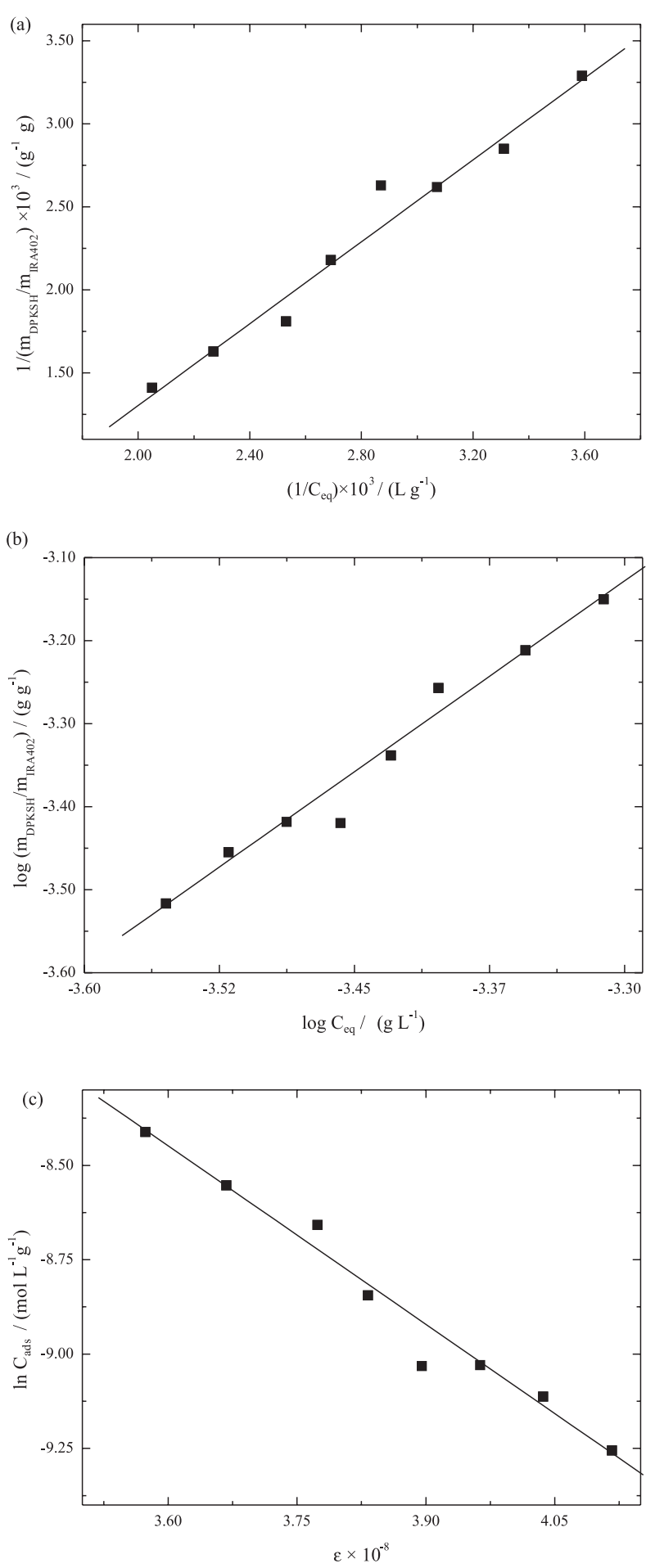

Figure 3. Adsorption isotherms of DPKSH onto IRA 402 at $\mathrm{pH} 12$ $\left(\mathrm{T}=25 \pm 1{ }^{\circ} \mathrm{C}\right.$ ). Solid lines correspond to fitting by the (a) Langmuir (b) Freundlich (c) Dubinin-Radushkevich models.

Dubinin-Radushkevich (D-R) isotherm model..$^{14,15,19}$ This model features energy heterogeneity over the entire surface. The linear form of the D-R isotherm is given by:

$\ln \mathrm{C}_{\mathrm{ads}}=\log \mathrm{K}_{\mathrm{DR}}-\mathrm{B} \varepsilon^{2}$ 
where $\mathrm{C}_{\mathrm{ads}}$ is the amount of DPKSH adsorbed per unit mass of IRA $402\left(\mathrm{~mol} \mathrm{~L}^{-1} \mathrm{~g}^{-1}\right), \mathrm{K}_{\mathrm{DR}}$ is the maximum amount of DPKSH adsorbed, B is a constant with dimensions of energy and $\varepsilon$ indicates the Polanyi potential $(\varepsilon=\mathrm{RT} \ln [1+$ $\left.\left(1 / \mathrm{C}_{\mathrm{eq}}\right)\right]$ ), where $\mathrm{R}$ is the gas constant in $\mathrm{kJ} \mathrm{K}^{-1} \mathrm{~mol}^{-1}$ and $\mathrm{T}$ is the temperature in $\mathrm{K}$.

Figure $3 \mathrm{c}$ shows the linear regression of the equation $\ln \mathrm{C}_{\text {ads }} v s . \varepsilon^{2}$. The values of $\mathrm{B}$ and $\mathrm{K}_{\mathrm{DR}}$ were obtained from the slope and intercept yielding $(-1.58 \pm 0.01) \times 10^{-8} \mathrm{~J}^{2} \mathrm{~mol}^{-2}$ and $(6.29 \pm 0.01) \times 10^{-2} \mathrm{~mol} \mathrm{~g}^{-1}$ at $\mathrm{pH} 12$.

According to Antonio et al. ${ }^{14}$ Freitas et al. ${ }^{15}$ and Saeed et al..$^{24}$ if the surface is considered heterogeneous and an approximation to a Langmuir isotherm is chosen as a local isotherm for sites that are energetically equivalent, then the quantity $\mathrm{B}^{1 / 2}$ can be related to the average sorption energy (E) as:

$$
\mathrm{E}=\frac{1}{\sqrt{-2 \mathrm{~B}}}
$$

which is the mean free energy of the transfer of $1 \mathrm{~mol}$ of solute from infinity to the surface of IRA 402.

The numerical value of $\mathrm{E}$, calculated from equation 10 , is $5.62 \mathrm{~kJ} \mathrm{~mol}^{-1}$ at pH 12 , indicating physical adsorption. ${ }^{14,15}$

\section{Flow injection procedure}

Originally, some significant parameters in the method development that can also considerably influence sensitivity, such as preconcentration time, sample flow rate, $\mathrm{pH}$, eluent volume, concentration and flow rate, reagent volume and concentration, and reaction coil size were optimized.

The loading time effect (preconcentration time) which influences the sample volume and analyte retention on the solid phase was evaluated ranging from 30 to $90 \mathrm{~s}(30,45$, 60,75 and $90 \mathrm{~s}$ ) with a $63.5 \mu \mathrm{g} \mathrm{L}{ }^{-1} \mathrm{Cu}$ (II) solution at $\mathrm{pH} 4.7$ and with a flow rate of $4.0 \mathrm{~mL} \mathrm{~min}^{-1}$. A linear development in the analytical signal (A) was observed due to the increase in the preconcentration time (t) to $60 \mathrm{~s}$ and can be described by the equation $\mathrm{A}=(8.7 \pm 0.5) \times 10^{-2}+(3.0 \pm 0.1) \times 10^{-3} t$ $(\mathrm{r}=0.996)$. Thus, under the experimental conditions, the solid phase was not saturated until a $60 \mathrm{~s}$ loading time was reached. Therefore, a $60 \mathrm{~s}$ loading time was chosen for subsequent experiments.

The analytical signal can also be influenced by the sample flow rate. At a constant loading time, the analytical signal tends to enlarge with an increase in flow rate, which is evidenced by an increase in the amount of analyte that interacts with the adsorbent. However, the kinetics of adsorption needs to be considered and the retention efficiency can diminish with low sample residence time in the column. Excessively high flow rates can also cause fluid leakage from the connection points due to an increase of backpressure. The flow rate (q) between 1.8 and $10.8 \mathrm{~mL}$ $\mathrm{min}^{-1}$ was evaluated under experimental conditions similar to those previously described. The analytical signal varied linearly from 1.8 to $6.3 \mathrm{~mL} \mathrm{~min}^{-1}$ according to the equation: $\mathrm{A}=(7.6 \pm 0.2) \times 10^{-2}+0.133 \pm 0.007 \mathrm{q}, \mathrm{r}=0.999$. Thus, showing that favorable kinetics is involved in metal retention until a flow rate of $6.3 \mathrm{~mL} \mathrm{~min}^{-1}$ is reached.

The effect of acidity on copper retention was investigated from $\mathrm{pH} 4.0$ to 7.0 using appropriate buffer solutions. An increase in $\mathrm{pH}$ led to an increase in the analytical signal, as shown in Figure 4a. The increase in analytical signal was significant until pH 5.5 and was approximately 53\% higher than observed at $\mathrm{pH}$ 4.0. A pH greater than 7.0 was not evaluated due to the fact that the metal hydrolysis was more favorable. Thus, a buffer solution with a $\mathrm{pH}$ of 5.5 was chosen for further experiments.

The efficiency of $\mathrm{Cu}^{2+}$ elution was evaluated using $\mathrm{HNO}_{3}$ in varying concentrations, volumes and flow rates. As shown in Figure $4 \mathrm{~b}, \mathrm{HNO}_{3}$ concentrations up to $0.10 \mathrm{~mol} \mathrm{~L}^{-1}$ were evaluated and the difference in the resulting analytical signals was not significant. The protonation of DPKSH is favorable in the presence of a high concentration of $\mathrm{H}^{+}$and this leads to competition between $\mathrm{H}^{+}$and metal ions for binding sites on the modified resin. However, higher eluent concentrations should be avoided to minimize desorption of complexant from the solid phase. Thus, $0.05 \mathrm{~mol} \mathrm{~L}^{-1} \mathrm{HNO}_{3}$ concentration was maintained in further experiments.

A slightly higher analytical signal was achieved with an increase in eluent volume from 100 to $150 \mu \mathrm{L}$. However, a decrease in the analytical signal $(-2.8 \%)$ was observed with $200 \mu \mathrm{L}$ of $\mathrm{HNO}_{3}$ due to greater dilution of the analyte, as shown in Figure 4c. Therefore, an eluent volume of $100 \mu \mathrm{L}$ was chosen for subsequent experiments.

The eluent flow rate was investigated between 1.8 and $10.4 \mathrm{~mL} \mathrm{~min}^{-1}$. As shown in Figure $4 \mathrm{~d}$, the increase in the analytical signal was proportional to the eluent flow rate to $6.3 \mathrm{~mL} \mathrm{~min}^{-1}$, demonstrating favorable desorption kinetics. Excessive flow rates may cause fluid leakage, which was observed at the sample flow rate. For further studies, an eluent flow rate of $6.3 \mathrm{~mL} \mathrm{~min}^{-1}$ was used.

The DPKSH concentration was varied at $(1.5,3.0$ and 6.0) $\times 10^{-4} \mathrm{~mol} \mathrm{~L}^{-1}$ at $\mathrm{pH}$ 5.5. The differences between analytical signals were low (ca. 1.4\%), therefore, a DPKSH concentration of $1.5 \times 10^{-4} \mathrm{~mol} \mathrm{~L}^{-1}$ was selected.

As observed with high eluent volumes, a higher dispersion of the sample zone can cause a decrease in analytical signals. This effect was also observed with an increase in reagent flow rate, shown in Figure 4e. Above 

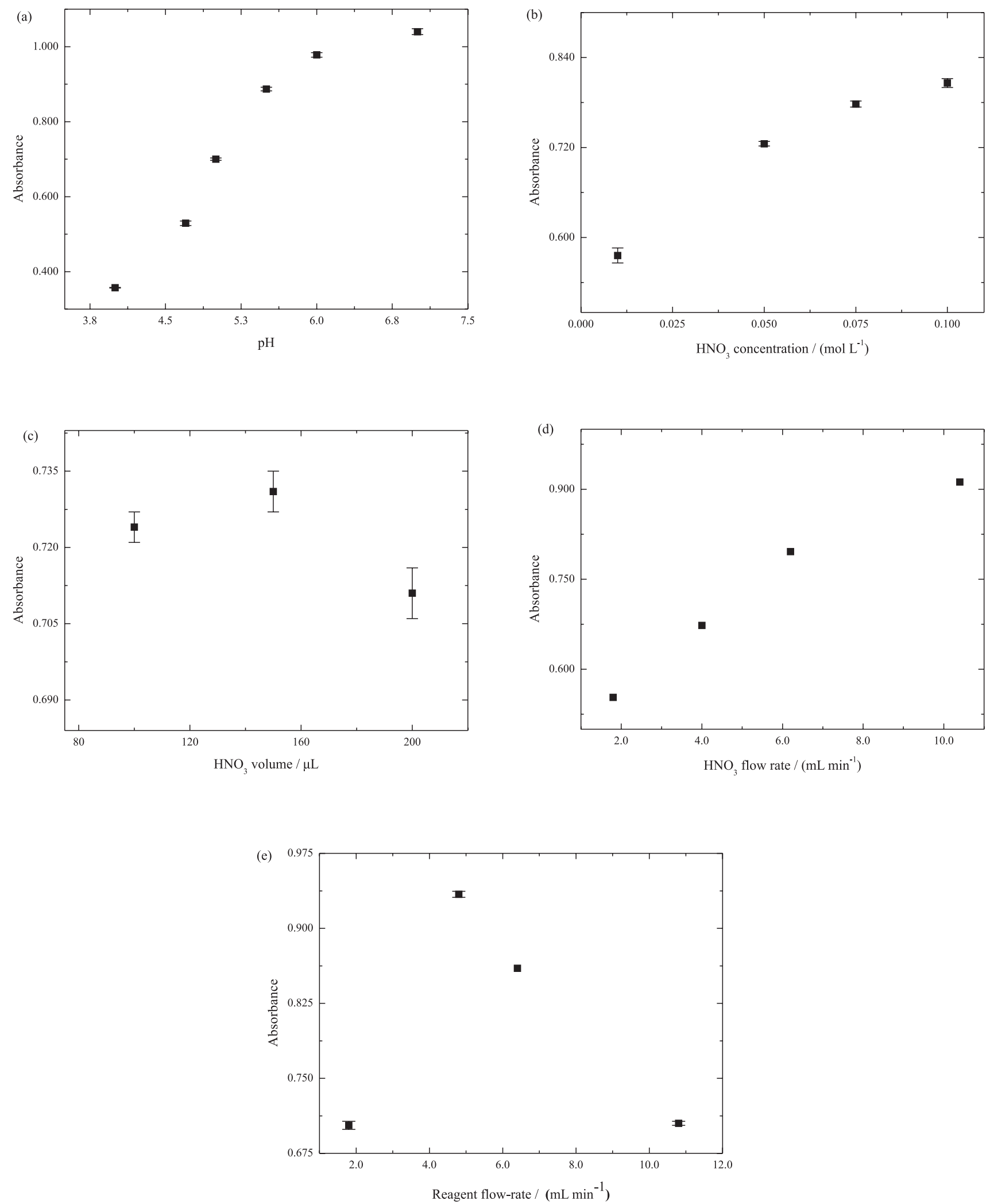

Figure 4. Effect of the (a) $\mathrm{pH}$ of the buffer solution, (b, c and d) eluent concentration, volume and flow rate and (e) reagent flow rate on the analytical signal for a $60 \mathrm{~s}$ loading time and a sample flow rate of $6.3 \mathrm{~mL} \mathrm{~min}^{-1}$. 
$4.8 \mathrm{~mL} \mathrm{~min}^{-1}$, a significant decrease in analytical signal was observed. Thus, a reagent flow rate of $4.8 \mathrm{~mL} \mathrm{~min}^{-1}$ was chosen for further experiments.

The effect of the reaction coil (RC) length (10, 30 and $50 \mathrm{~cm}$ ) was evaluated. A decrease in analytical signal was observed with an increase in the length of the reaction coil due to greater dispersion of the sample zone. Therefore, a reaction coil length of $10 \mathrm{~cm}$ was chosen.

\section{Analytical features}

Using the flow system shown in Figure 1, analytical curves were obtained by pumping aliquots of $\mathrm{Cu}$ (II) standard solutions of varying concentrations, with measurements made in triplicate. A linear response was observed from 0.31 to $1.26 \mu \mathrm{mol} \mathrm{L} \mathrm{L}^{-1}$. This behavior can be described by the equation $\mathrm{A}=(2.6 \pm 0.4) \times 10^{-2}+(2.48 \pm$ $0.04) \times 10^{5} \mathrm{C}_{\mathrm{Cu}(\mathrm{III}}, \mathrm{r}=0.997$, where $\mathrm{A}$ is the absorbance measured as peak height and $\mathrm{C}$ is the $\mathrm{Cu}(\mathrm{II})$ concentration in $\mathrm{mol} \mathrm{L}^{-1}$.

The limits of detection and quantification were estimated at 0.5 and $1.8 \mu \mathrm{g} \mathrm{L}^{-1}$ of $\mathrm{Cu}$ (II) according to IUPAC recommendations at the $95 \%$ confidence level ${ }^{25}$ with an enrichment factor of 11 . The relative standard deviation was estimated as $2.6 \%$ for 20 independent measurements with a $32 \mu \mathrm{g} \mathrm{L}{ }^{-1} \mathrm{Cu}$ (II) solution. The sampling throughput for a $60 \mathrm{~s}$ loading time was 55 samples per hour. The resin modified by the addition of DPKSH was used for at least 288 sampling cycles without significant variation in the analytical response.

\section{Effect of foreign ions}

Under optimized conditions, experiments were conducted to evaluate the selectivity of the proposed procedure. The effect of cations and anions often found in different samples was evaluated and the results are presented in Table 1. The tolerance limit (7.8\%) was taken as three times the standard deviation $( \pm 0.004)$ of the average of analytical signal (0.153) for tenfold measurement for solutions with no interfering species.

Some cations and anions $\left(\mathrm{Na}^{+}, \mathrm{K}^{+}, \mathrm{Co}^{2+}, \mathrm{Cl}^{-}, \mathrm{NO}_{3}^{-}\right.$, $\mathrm{F}^{-}, \mathrm{CH}_{3} \mathrm{COO}^{-}$and $\mathrm{SO}_{4}{ }^{2-}$ ) yield only a slight interference when the concentration of interfering ion was 1000 fold greater than the concentration of $\mathrm{Cu}(\mathrm{II})\left(63.5 \mu \mathrm{g} \mathrm{L} \mathrm{L}^{-1}\right)$. However, $\mathrm{Co}^{2+}$ was an exception and caused a relevant interference at concentrations 1000 times greater than the concentration of $\mathrm{Cu}(\mathrm{II}) . \mathrm{HCO}_{3}{ }^{-}$and $\mathrm{PO}_{4}{ }^{3-}$ caused interferences when their concentrations were 100 times greater than $\mathrm{Cu}(\mathrm{II})$. Similar effects were observed for $\mathrm{Mg}^{2+}, \mathrm{Ca}^{2+}, \mathrm{Pb}^{2+}, \mathrm{Cd}^{2+}, \mathrm{Zn}^{2+}, \mathrm{Mn}^{2+}, \mathrm{Fe}^{3+}$ and $\mathrm{Cr}^{3+}$ when
Table 1. Tolerance limit of foreign ions on determination of $63.5 \mu \mathrm{g} \mathrm{L}^{-1}$ $\mathrm{Cu}(\mathrm{II}), \mathrm{pH}=5.5, \lambda=378 \mathrm{~nm}, 95 \mathrm{mg}$ modified resin

\begin{tabular}{lc}
\hline Foreign ion & Tolerance Limit \\
\hline Ascorbate & $\geq 10.000$ \\
$\mathrm{Na}^{+}, \mathrm{K}^{+}, \mathrm{Co}^{2+}, \mathrm{Cl}^{-}, \mathrm{F}^{-}, \mathrm{NO}_{3}^{-}$, & $\geq 1.000$ \\
$\mathrm{CH}_{3} \mathrm{COO}^{-}, \mathrm{SO}_{4}^{2-}$ & $\geq 100$ \\
$\mathrm{HCO}_{3}^{--}, \mathrm{PO}_{4}^{3-}$ & $\geq 10$ \\
$\mathrm{Mg}^{2+}, \mathrm{Ca}^{2+}, \mathrm{Pb}^{2+}, \mathrm{Cd}^{2+}, \mathrm{Ni}^{2+}$, & \\
$\mathrm{Zn}^{2+}, \mathrm{Mn}^{2+}, \mathrm{Fe}^{3+}, \mathrm{Cr}^{3+}$ & $\geq 1$ \\
$\mathrm{Al}^{3+}$ & \\
\hline
\end{tabular}

present in concentrations that were 10 times higher than $\mathrm{Cu}(\mathrm{II})$. Low $\mathrm{Cu}$ (II) retention in the presence of these ions may be attributed to competition for adsorption sites. Only $\mathrm{Al}^{3+}$ yields a serious interference when present in concentrations equivalent to $\mathrm{Cu}(\mathrm{II})$.

By comparing the absorption maximum wavelength and molar absorptivity of complexes $\mathrm{Cu}(\mathrm{II}) / \mathrm{DPKSH}$ $3.6 \times 10^{4} \mathrm{~L} \mathrm{~mol}^{-1} \mathrm{~cm}^{-1}$ at $378 \mathrm{~nm}, \mathrm{Ni}(\mathrm{II}) / \mathrm{DPKSH}$ $4.9 \times 10^{4} \mathrm{~L} \mathrm{~mol}^{-1} \mathrm{~cm}^{-1}$ at $375 \mathrm{~nm}$ and $\mathrm{Co}(\mathrm{II}) / \mathrm{DPKSH}$ $4.3 \times 10^{4} \mathrm{~L} \mathrm{~mol}^{-1} \mathrm{~cm}^{-1}$ at $375 \mathrm{~nm},{ }^{16}$ the positive interference caused by $\mathrm{Ni}^{2+}$ and $\mathrm{Co}^{2+}$, at concentrations 10 times greater than the concentration of $\mathrm{Cu}^{2+}$, may take place as a result of a competition between these ions for modified resin active sites resulting in an increased absorbance value from the elution of $\mathrm{Cu}$ (II) and $\mathrm{Ni}^{2+}$ or $\mathrm{Cu}$ (II) and $\mathrm{Co}$ (II). $\mathrm{Zn}$ (II)/DPKSH complex also shows a molar absorptivity value $5.3 \times 10^{4} \mathrm{~L} \mathrm{~mol}^{-1} \mathrm{~cm}^{-1}{ }^{16}$ greater than $\mathrm{Cu}(\mathrm{II}) / \mathrm{DPKSH}$, however the absorption maximum wavelength of such complex corresponds to $360 \mathrm{~nm}$.

The interference of metallic ions commonly present in ethanol fuel samples, such as $\mathrm{Ni}, \mathrm{Zn}, \mathrm{Cd}$ and $\mathrm{Co}^{26,27}$ are

Table 2. Recovery of copper spiked and determination of copper in ethanol fuel samples by proposed procedure and F AAS ${ }^{30}$

\begin{tabular}{lccc}
\hline Samples & \multicolumn{3}{c}{ Copper amount / $\left(\mathrm{mg} \mathrm{L}^{-1}\right)$} \\
\hline & Added & Found & Recovery / (\%) \\
A & 0.060 & $0.062 \pm 0.002$ & $103 \pm 4$ \\
& 0.080 & $0.077 \pm 0.001$ & $97 \pm 1$ \\
\hline B & Proposed procedure & F AAS & \\
C & $0.021 \pm 0.004$ & $0.024 \pm 0.007$ & \\
D & $0.0042 \pm 0.0013$ & $<0.011^{*}$ & \\
E & $0.018 \pm 0.005$ & $0.016 \pm 0.008$ & \\
F & $0.045 \pm 0.003$ & $0.047 \pm 0.003$ & \\
G & $0.037 \pm 0.007$ & $0.032 \pm 0.005$ & \\
H & $0.028 \pm 0.009$ & $0.028 \pm 0.006$ & \\
\hline
\end{tabular}

"< limit of detection. 
Table 3. Analytical features of some procedures for copper determination

\begin{tabular}{|c|c|c|c|c|c|c|}
\hline Solid Phase & $\begin{array}{c}\text { Sample } \\
\text { frequency / }\left(\mathrm{h}^{-1}\right)\end{array}$ & $\begin{array}{l}\text { Limit of detection / } \\
\qquad\left(\mu \mathrm{g} \mathrm{L}^{-1}\right)\end{array}$ & $\begin{array}{l}\text { Coefficient of } \\
\text { variation / }(\%)\end{array}$ & $\begin{array}{l}\text { Enrichment } \\
\text { factor }\end{array}$ & $\begin{array}{c}\text { Sample } \\
\text { volume / } \mathrm{mL}\end{array}$ & Reference \\
\hline Peat Sorb ${ }^{\circledR}$ & 12 & 3.2 & 3.3 & 16 & 13.6 & 10 \\
\hline $\begin{array}{l}\text { XAD-4 } \\
\text { functionalized }^{\text {a }}\end{array}$ & 51 & 1.1 & 2.5 & 29 & 5 & 12 \\
\hline XAD-4 loaded ${ }^{\text {a }}$ & 51 & 1.0 & 1.9 & 29 & 5 & 12 \\
\hline PUF/Me-BDBD & - & 3.4 & 3.2 & 7 & - & 31 \\
\hline XAD-4/PAR & - & 2.8 & 1.1 & 7.4 & 2.5 & 32 \\
\hline IRA 402/DPKSH & 55 & 0.5 & 2.8 & 11 & 6.3 & proposed procedure \\
\hline
\end{tabular}

a $\beta$-nitroso- $\alpha$-naphthol; PUF polyurethane foam; Me_BDBD 6-[2'-(6'-methyl-benzothilazolylazo)]-1,2-dihydroxy-3,5-benzenedisulfonic acid; PAR 4-(2-pyridylazo) resorcinol.

not relevant to the proposed procedure, since these species are typically found at levels similar or lower than $\mathrm{Cu}(\mathrm{II})$. However, Fe(III) is a concomitant commonly present at levels similar or higher than $\mathrm{Cu}$ (II) and must be masked. Based on the values of complexes formation constants $\mathrm{Fe}(\mathrm{III}) / \mathrm{DPKSH}\left(\beta_{1} 2.9 \times 10^{5}\right)^{28}$ and $\mathrm{Fe}(\mathrm{III}) / \mathrm{F}^{-}\left(\beta_{6} 1.3 \times 10^{16}\right),{ }^{29}$ $\mathrm{Fe}(\mathrm{III})$ ions present in the ethanol fuel samples were masked in these samples by adding $\mathrm{F}^{-}$.

\section{Application to ethanol fuel samples}

The recovery of copper spiked into ethanol fuel samples was evaluated to verify the applicability of the proposed procedure (Table 2). Recoveries from 97 to $103 \%$ were estimated indicating that the procedure is free from matrix effects.

The results obtained from ethanol fuel samples by the proposed procedure were compared to those attained by $\mathrm{F} \mathrm{AAS},{ }^{30}$ Table 2, and are in agreement at the $99 \%$ confidence level.

Table 3 shows a comparison of analytical features of the proposed method and established methods for the determination of copper after solid-phase extraction. ${ }^{10,12,31,32}$ Features such as the limit of detection and enrichment factor are comparable to those obtained by the proposed method. A relevant number of methods have been proposed for the determination of cations from ethanol fuel samples and most of then use atomization techniques - these procedures also need a preconcentration step. ${ }^{33,34}$ Advantages of the proposed method include the determination of copper from ethanol fuel samples without the requirement of a pretreatment step, low consumption of sample and reagents and high limit of detection, as well as the UV-Vis spectrophotometric methods are seen as attractive possibilities for determining metallic ions due to their handling easiness and simplicity, low cost and easy access to instrumentation. ${ }^{35}$

\section{Conclusions}

IRA 402 resin was modified by the addition of DPKSH, and a kinetic and isotherm adsorption study was performed. The modified resin was used for at least 288 preconcentration/elution cycles to test endurance and reproducibility. The successful application of the proposed method for $\mathrm{Cu}$ (II) determination in ethanol fuel samples, without the need for pretreatment such as evaporation, shows the feasibility of IRA 402 resin modified by DPKSH as a solid phase in solid-liquid extraction.

\section{Acknowledgments}

The authors acknowledge fellowships and financial support from the following Brazilian agencies: Coordenação de Aperfeiçoamento de Pessoal de Nível Superior (CAPES), Conselho Nacional de Desenvolvimento Científico e Tecnológico (CNPq) and Fundação de Amparo à Pesquisa do Estado de São Paulo (FAPESP).

\section{References}

1. Lemos, V. A.; Santos, M. S.; Santos, E. S.; Santos, M. J. S.; Santos, W. N. L.; Souza, A. S.; Jesus, D. S.; Virgens, C. F.; Carvalho, M. S.; Oleszczuk, N.; Vale, M. G. R.; Welz, B.; Ferreira, S. L. C.; Spectrochim. Acta, Part B 2007, 62, 4.

2. Ferreira, S. L. C.; de Andrade, J. B.; Korn, M. G. A.; Pereira, M. G.; Lemos, V. A.; dos Santos, W. N. L.; Rodrigues, F. M.; Souza, A. S.; Ferreira, H. S.; da Silva, E. G. P.; J. Hazard. Mater. 2007, 145, 358.

3. Korn, M. G. A.; de Andrade, J. B.; Jesus, D. S.; Lemos, V. A.; Bandeira, M.L. S.F.; dos Santos, W.N.L.; Bezerra, M.A.;Amorim, F. A. C.; Souza, A. S.; Ferreira, S. L. C.; Talanta 2006, 69, 16.

4. Camel, V.; Spectrochim. Acta, Part B 2003, 58, 1177.

5. Ávila-Terra, L. H. S.; Gaubeur, I.; Areias, M. C. C.; Suárez-Iha, M. E. V.; Spectrosc. Lett. 1999, 32, 257. 
6. Xie, F.; Lin, X.; Wu, X.; Xie, Z.; Talanta 2008, 74, 836.

7. Gaubeur, I.; Ávila-Terra, L. H. S.; Masini, J. C.; Suárez-Iha, M. E. V.; Anal. Sci. 2007, 23, 1227.

8. Hansen, E. H.; Miró, M.; TrAC, Trends Anal. Chem. 2007, 26, 18.

9. Tzanavaras, P. D.; Themelis, D. G.; Anal. Chim. Acta 2007, $588,1$.

10. Gonzáles, A. P. S.; Firmino, M. A.; Nomura, C. S.; Rocha, F. R. P.; Oliveira, P. V.; Gaubeur, I.; Anal. Chim. Acta 2009, 636, 198.

11. Baliza, P. X.; Ferreira, S. L. C.; Texeira, L. S. G.; Talanta 2009, $79,2$.

12. Lemos, V. A.; Santos, E. S.; Gama, E. M.; Sep. Purif. Technol. 2007, 56, 212.

13. Antonio, P.; Iha, K.; Suárez-Iha, M. E. V.; J. Colloid Interface Sci. 2007, 307, 24.

14. Antonio, P.; Iha, K.; Suárez-Iha, M. E. V.; Talanta 2004, 64, 484.

15. Freitas, P. A. M.; Iha, K.; Felinto, M. C. F. C.; Suárez-Iha, M. E. V.; J. Colloid Interface Sci. 2008, 323, 1.

16. Garcia-Vargas, M.; Belizón, M.; Hernández-Artiga, M. P.; Martinez, C.; Pérez-Bustamante, J. A.; Appl. Spectrosc. 1986, 40, 1058.

17. Takeuchi, R. M.; Santos, A. L.; Medeiros, M. J.; Stradiotto, N. R.; Microchim. Acta 2009, 164, 101.

18. Chen, H.; Zhao, J.; Adsorption 2009, 15, 381.

19. Solangi, I. B.; Memon, S.; Bhanger, M. I.; Anal. Chim. Acta 2009, 638, 146.

20. Nadeem, M.; Mahmood, A.; Shahid, S. A.; Shah, S. S.; Khalid, A. M.; McKay, G.; J. Hazard. Mater. 2006, 138, 604.

21. Mall, I. D.; Srivastava, V. C.; Agarwal, N. K.; Dyes Pigm. 2006, $69,210$.
22. Langmuir, I.; J. Am. Chem. Soc. 1918, 40, 1361.

23. Freundlich, H. M. F.; J. Phys. Chem. 1906, 57, 385.

24. Saeed, M. M.; Hasany, S. M.; Ahmed, M.; Talanta 1999, 50, 625.

25. Analytical Methods Committee; Analyst 1987, 112, 199.

26. Tartarotti, F. O.; Oliveira, M. F.; Balbo, V. R.; Stradiotto, N. R.; Microchim. Acta 2006, 155, 397.

27. Teixeira, L. S. G.; Brasileiro, J. F.; Borges Junior, M. M.; Cordeiro, P. W. L.; Rocha, S. A. N.; Costa, A. C. S.; Quim. Nova 2006, 29, 741.

28. Gaubeur, I.; Areias, M. C. C.; Terra, L. H. S. A.; Suárez-Iha, M. E. V.; Spectrosc. Lett. 2002, 35, 455.

29. Lurie, J.; Handbook of Analytical Chemistry, English Translation, Mir Publishers: Moscow, 1975.

30. Associação Brasileira de Normas Técnicas ABNT.; Ethanol - Determination of Iron and Copper Content - Flame Atomic Absorption Spectrometric Method, NBR 11331, 2007. http://www.abntcatalogo.com.br/norma.aspx?ID=38521

31. Lemos, V. A.; Vieira, D. R.; Novaes, C. G.; Rocha, M. E.; Santos, M. S. S.; Yamaki, R. T.; Microchim. Acta 2006, 153, 193.

32. Yebra, M. C.; Carro, N.; Moreno-Cid, A.; Spectrochim. Acta, Part B 2002, 57, 85.

33. Oliveira, M. F.; Saczk, A. A.; Okumura, L. L.; Stradiotto, N. R.; Energy Fuels 2009, 23, 4852.

34. Saint Pierre, T.; Aucélio, R. Q.; Curtius, A. J.; Microchem. J. 2003, 75, 59.

35. Matsuokaa, S.; Yoshimura, K.; Anal. Chim. Acta 2010, 664, 1.

Submitted: June 30, 2010

Published online: November 4, 2010

FAPESP has sponsored the publication of this article. 